\author{
Daniel Chi Wing HO \\ Yung YAU \\ Chi Kwong LAW \\ Sun Wah POON \\ Hak Kwong YIP \\ Ervi LIUSMAN
}

\title{
Social sustainability in urban renewal: An assessment of community aspirations
}

The lack of a proper building care culture has led to serious problems of urban decay in most developed cities, threatening community health and safety. To arrest urban decay, redevelopment is a commonly adopted approach for regenerating rundown areas. Redevelopment often results in negative outcomes such as disturbances to existing social networks and burgeoning construction and demolition waste. On the other hand, building rehabilitation is a more socially and environmentally friendly alternative to redevelopment, but its success depends much on residents' active participation. With a view towards a sustainable strategy for urban renewal, it is necessary to balance the interests of different stakeholders regarding the choice between these two mainstream approaches to renewal. Although economic and physical issues are important decision-making considerations, this study explores the aspirations and preferences of local residents in relation to the two options through a structured survey. The findings are conducive to the development of a balanced and socially sustainable strategy of urban renewal.

Key words: social sustainability, building rehabilitation, redevelopment, urban renewal, community aspirations 


\section{Introduction}

Most developed cities face the formidable problem of urban decay (Chan \& Lee, 2008a; Yau, 2008; Yau, 2009; Yau \& Cheng, 2010). A holistic policy for the long-term management of their building stock is often absent, and there is a general lack of a building-care culture among homeowners in multi-owned apartment buildings. Building dilapidation proliferates, particularly in old districts, and threatens community health and safety. This issue has been widely discussed in the literature (e.g., Ho \& Yau, 2004; Ho et al., 2008; Yau, Ho, et al., 2008; Yau et al., 2009; Yau, 2010). To take Hong Kong as an example, the local community has been suffering from tragedies caused by derelict buildings. In January 2010, for instance, an old and unmanaged six-storey apartment building collapsed, causing four deaths. This incident represents only the tip of the iceberg. According to the Home Affairs Department (2010), among the 39,500 private buildings in Hong Kong, about 25\% do not have any form of residents' organisation. Moreover, two-fifths of the building stock is not managed by any property management agent. Most of these unmanaged buildings are, in fact, old and probably the most dilapidated of all.

It is a common belief that building dilapidation and urban decay should be urgently improved by means of urban renewal or regeneration. Yet building rehabilitation and renovation projects are often hindered by a lack of funding or lack of cooperation between building co-owners. More importantly, a set of general principles guiding the use of redevelopment or rehabilitation to a particular urban renewal project is often absent among the responsible local authorities. This creates disputes among various stakeholders and delays the renewal process. In light of the far-reaching impacts of urban renewal on the quality of the built environment and quality of life (Shye, 1989; $\mathrm{Ng}$ et al., 2005), due consideration should be accorded to a wide spectrum of perspectives (e.g., economic, physical and social) when deciding on the best option for a renewal project.

There has been a large body of literature discussing various aspects of urban renewal, such as the physical conditions of buildings (e.g., Ho et al., 2004; Wong et al., 2006; Yau, 2008; Juan et al., 2010) and the economics of building improvement (e.g., Needleman, 1969; Balchin et al., 1992; Yiu, 2007; Ribeiro, 2008; Yau, Chau, et al., 2008; Yau, 2011). Nonetheless, the community aspirations for different approaches to urban renewal have seldom attracted academic attention. To straddle the existing research gap, this study aims to assess how the community perceives the two approaches to urban renewal, namely redevelopment and rehabilitation, through a structured survey. In particular, we aim to identify exogenous factors affecting an individual's attitude towards these two approaches. Policy implications would be discussed with respect to the community engagement process for a balanced and socially sustainable urban renewal strategy.

\section{Urban renewal and social sustainability \\ 2.1 Redevelopment vs. rehabilitation}

A sustainable strategy for urban renewal should embrace different options for action. Redevelopment usually aims to eliminate the existing rundown areas or prevent an existing area from turning into a slum (Warren, 1965). If properly planned and executed, redevelopment projects can thoroughly improve the built environment in the subject areas. Stephen Messner (1968) and Christine Stevens (1995) pointed out that the capital investment stemming from redevelopment could offer social and economic benefits to local communities. Certain social problems, such as crime and poor environmental hygiene, could be reduced after the removal of poor-quality structures in rundown areas. Additionally, properties in the vicinity of redeveloped areas could become more valuable. Stevens (1995) added that redevelopment could bring about significant indirect economic benefits by creating jobs and improving economic activity.

Nevertheless, redevelopment often results in massive building demolition and the displacement of existing residents (Stevens, 1995; Arthurson, 1998). It destroys the existing social fabric and networks, leading to social isolation. Marc Fried (1966), Stevens (1995) and Larry Keating (2000) believed that redevelopment can create disruptions to individuals and communities and reduce social capital as a whole. The Port Adelaide waterfront redevelopment, for instance, has caused the working class in that area to suffer due to the relocation of export shipping activities, which has diminished economic prosperity (Oakley, 2007). Susan Oakley (2007) also mentioned that the majority of local residents are concerned about the negative impact of redevelopment on the continuity of a "sense of place". This is contrary to the principles of community building in the contemporary urban planning concept. In addition to these social problems, redevelopment also damages the environment. For instance, Vivian Tam and Chi-Ming Tam (2007) criticised Hong Kong's comprehensive redevelopment projects for generating a huge volume of concrete waste that would soon exhaust all the available landfill areas. In addition, in typical redevelopment projects, old and relatively low-rise buildings are torn down and replaced by new high-rises. The erection of these high-rises may affect the natural lighting and air circulation in the neighbourhood. An increased development density can be detrimental to a community's health (Jackson, 2003). 
On the other hand, building rehabilitation is more socially friendly because it upgrades the physical built environment without relocating the residents. Building rehabilitation is important in regenerating old urban areas (Hui et al., 2008) and is needed to open the potentialities of city life to the local communities (Ogdul, 2000). It causes less social disturbance (Needleman, 1965) and is a cheaper and faster method to enhance the building quality (Yau \& Ho, 2008). Robert Simons et al. (2003) listed the economic and social benefit of the Community Development Corporations (CDC)'s housing rehabilitation programs, including job creation, increasing property values, improved quality of housing, provision of low-income households with affordable housing, and improved neighbourhood stability. A number of European countries have replaced redevelopment with an emphasis on rehabilitation in urban regeneration since the 1970s (Wood, 1991) because rehabilitation improves building quality, strengthens residents' identity and contributes to the decrease of social asymmetries (Mourao \& Pedro, 2007). In addition, rehabilitation adds value to both the improved properties and those nearby (O'Loughlin \& Munski, 1979; Yau, Chau, et al., 2008).

From an environmental viewpoint, rehabilitation is a means of increasing housing space supply with a low expenditure of energy and material consumption. It also preserves building materials and develops tourism opportunities (McLaren, 1989). Rehabilitation, one of the methods for upgrading the building quality of existing stocks, is very important for enhancing the sustainability of the built environment (Cooper, 2001). This is why Nessa Winston (2010) recommended that a sustainable urban renewal policy should put more emphasis on rehabilitation rather than demolition.

\subsection{Urban renewal and social sustainability}

Urban sustainability has become an important issue when increasingly more cities are experiencing considerable physical, economic and social transformations. Nicola Dempsey et al. (in press) pointed out that sustainable development should not be solely an ecological or environmental issue, but should also encompass physical, economic and social dimensions. This is particularly true when the concept of sustainable development is applied to the arena of urban management, including urban renewal. Given that the primary objective of urban renewal is to improve the quality of life for the community affected, the physical improvement of its built environment alone is insufficient (Planning and Lands Bureau, 2001). As put forward by Peter Roberts (2000), urban physical conditions are strongly linked to social responses. Urban renewal often creates new social problems. For example, inadequate compensation, lack of residents' participation in the renewal process and the unavailability of the option for original residents to return to the redeveloped areas often damages the diversity and vitality of the neighbourhoods (Jacobs, 1961; Hartman, 1964). In addition, urban renewal, particularly in the form of redevelopment, may destroy families, kinship and the social networks of long-established communities (Willmott \& Young, 1957; Meegan \& Mitchell, 2001; He \& Wu, 2007). Patrick Loftman and Brendan Nevin (1995) emphasised that the negative outcomes of urban renewal would be more profound for the disadvantaged, such as those with low incomes and the elderly.

Because social capital plays a certain role in sustainable development (Danchev, 2005), planners should duly consider various social issues so that they can map out a sustainable strategy of urban renewal for a city (Price Waterhouse, 1993; Edwards, 1997; Roberts, 2000; Stubbs, 2004; Friedman, 2007). A successful renewal project improves the life opportunities of the existing residents and promotes social cohesion and a sense of belonging in the area (Arthurson, 1998). To a large extent, renewal projects of this kind can achieve urban social sustainability, which is defined by Oren Yiftachel and David Hedgcock (1993: 140) as: "[t] he continuing ability of a city to function as a long-term viable setting for human interaction, communication and cultural development." With a view to social sustainability in urban renewal, therefore, planners are required to comprehend the appropriate approach that brings fewer negative impacts to the existing social fabric and causes less reduction in social capital.

Many previous studies (e.g., Needleman, 1965; Brookes \& Hughes, 1975; Alker \& McDonald, 2003; Yiu \& Leung, 2005; Chan \& Lee, 2008b; Yau, Ho, et al., 2008) focused on the economic and physical dimensions of urban renewal. There has been little empirical literature that has demonstrated the relative significance of social networks in communities and the perceptions of their residents towards various urban renewal strategies. For instance, Michael Warren (1965) and John O'Loughlin and Douglas Munski (1979) highlighted that residents in the U.S. did not prefer housing rehabilitation because of the increased property taxes. Therefore, Richard Travis (1973) and O'Loughlin and Munski (1979) suggested that residents' attitude toward rehabilitation should be examined before its implementation. The same applies to other means of urban renewal. What is equally important is to consider the value placed by residents on their existing social environment in urban renewal (Brookes \& Hughes, 1975).

Although urban renewal or regeneration can contribute to a city's sustainable development through recycling dilapidated sites and buildings (Couch \& Dennemann, 2000), planning and implementing the projects in a "sustainable" manner can be challenging. In light of the divergent views and conflicting interests of different stakeholders, it is necessary to involve 
the local community in order to arrive at a more informed and socially responsible decision in urban renewal (Ng, 2002). Policymakers and administrators should bear in mind that sustainable development should be based on the understanding of close links between the environment and society with feedback loops that go both ways (Hopwood et al., 2005). Sustainability in urban renewal projects can only be achieved by engaging the community in the process (Fordham, 1995; Edgar \& Taylor, 2000).

All these studies explain why community involvement should be a major part of the urban renewal process in order to convert the aspirations of communities into decisions that benefit them (Warren, 1965; Jacobs \& Dutton, 2000; Lloyd, 2002), although Marilyn Taylor (2000) has cautioned that involving the community in the urban renewal process could be time-consuming and complex.

\section{Research design}

Given that community aspirations are important to successful urban renewal, this study aims to explore community perceptions towards the two mainstream approaches to urban renewal - namely, redevelopment and rehabilitation - and to identify the determinants of the average individual's attitude to these approaches. This study adopts a qualitative response method to collate the views of the residents living in four old districts in Hong Kong - Central and Western (CW), Wanchai (WC), Yau Tsim Mong (YTM) and Sham Shui Po (SSP) - with the use of a structured survey. These four districts were selected because of the proliferation of dilapidated buildings there. Figure 1 shows the generally dilapidated buildings in the SSP district. They also happened to be target areas for urban renewal under the Urban Renewal Strategy 2001 (Planning and Lands Bureau, 2001). Only residents living in private residential buildings were interviewed. Prior to the interview, the definitions of redevelopment and rehabilitation were explained to the residents. The questionnaire set includes questions about the responding residents' socio-demographic characteristics, residential experience, perceived conditions of social networks, attitudes toward redevelopment and rehabilitation, and reasons for their mindsets.

\subsection{Analytical model explaining an individual's attitude}

The preset questionnaire includes questions about a) the particulars of each respondent, such as age, educational level and household income; and b) attitudes toward the two urban renewal approaches and social conditions conducive to their

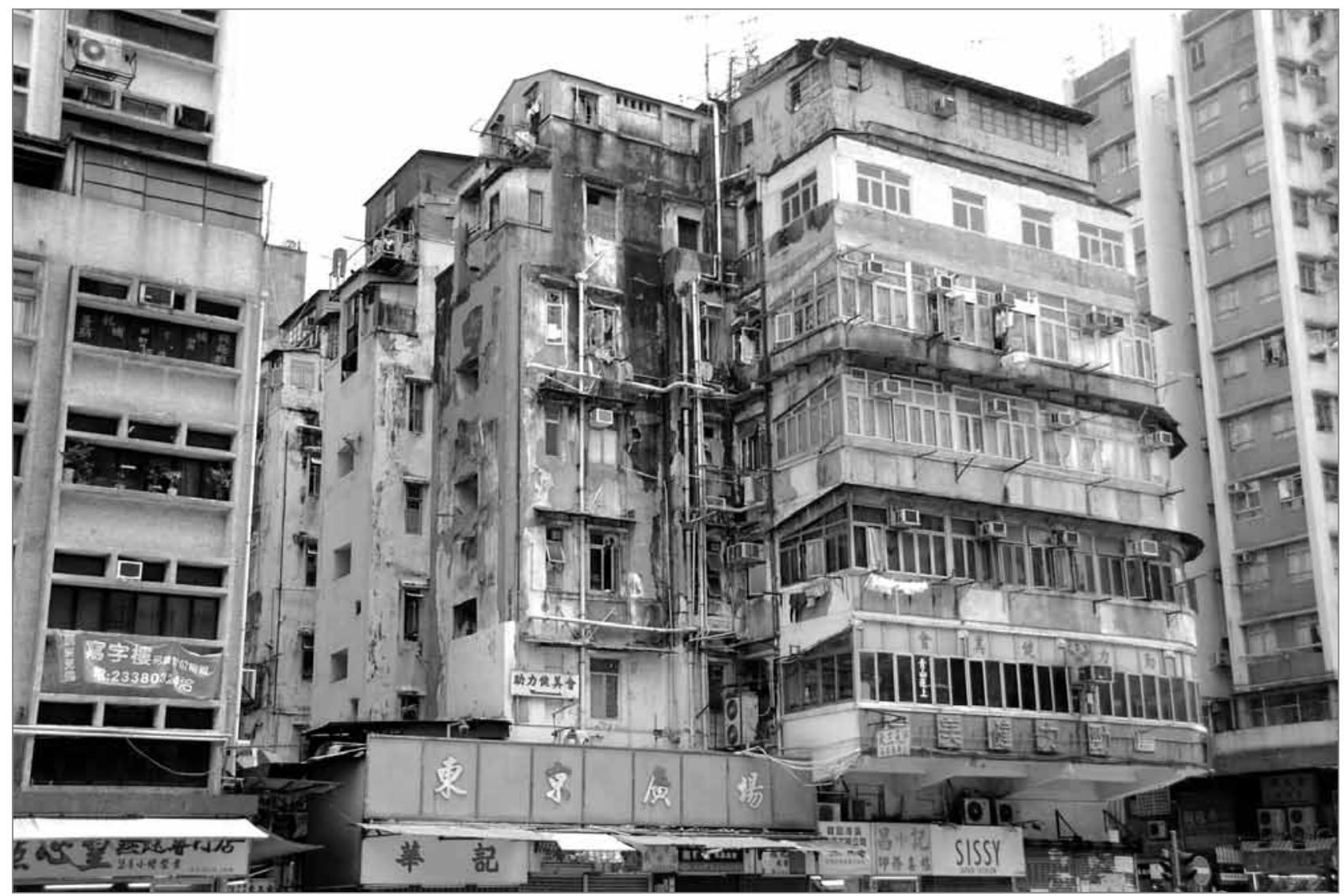

Figure 1: A dilapidated building in an old district in Hong Kong (photo: Daniel Chi Wing Ho). 
choices, such as length of residence, moving decision and social network. As suggested by the literature (e.g., Mendelsohn, 1977; Mayer, 1981; Shear, 1983), the choice between different renewal approaches could be influenced by household characteristics, building age, moving decision and neighbourhood features. Travis (1973) found that a resident's attitude towards housing rehabilitation depended on his or her socioeconomic background, length of residence in the neighbourhood and housing tenure. Based on these established links, we hypothesised that an individual's choice (CHOICE) between rehabilitation and redevelopment for an urban renewal project can be expressed as a function $(f)$, as shown in Equation 1:

CHOICE $=f(G E N, A G E, I N C, E D U, E M P, T E N, L O R$, ITS, BAGE, SAT, IFM, FSI, REL, DIST)

Where

- GEN, AGE, INC, EDU, EMP and TEN denote the gender, age, household income, highest educational attainment, employment status and tenure mode of the individual, respectively;

- LOR stands for an individual's length of residence at his or her current address;

Table 1: Descriptions of the explanatory variables.

\begin{tabular}{|c|c|c|}
\hline Variable & \multicolumn{2}{|c|}{ Description } \\
\hline \multicolumn{3}{|c|}{ Choice (CHOICE) } \\
\hline & $=-3$ & Strongly supported rehabilitation and opposed redevelopment \\
\hline & $=-2$ & Strongly supported rehabilitation \\
\hline & $=-1$ & Supported rehabilitation \\
\hline & $=0$ & Neutral between the two approaches \\
\hline & $=1$ & Supported redevelopment \\
\hline & $=2$ & Strongly supported redevelopment \\
\hline & $=3$ & Strongly supported redevelopment and opposed rehabilitation \\
\hline \multicolumn{3}{|c|}{ Gender (GEN) } \\
\hline & $=1$ & If the respondent is male, and zero if otherwise \\
\hline \multicolumn{3}{|c|}{ Resident Age (AGE) } \\
\hline & $=1$ & 19 years old or less \\
\hline & $=2$ & $20-29$ years old \\
\hline & $=3$ & $30-39$ years old \\
\hline & $=4$ & 40-49 years old \\
\hline & $=5$ & $50-59$ years old \\
\hline & $=6$ & $60-69$ years old \\
\hline & $=7$ & 70 years old or more \\
\hline \multicolumn{3}{|c|}{ Monthly Household Income (INC) } \\
\hline & $=1$ & Below HKD 6,000 \\
\hline & $=2$ & HKD 6,000-9,999 \\
\hline & $=3$ & HKD 10,000-14,999 \\
\hline & $=4$ & HKD 15,000-19,999 \\
\hline & $=5$ & HKD 20,000-24,999 \\
\hline & $=6$ & HKD 25,000-29,999 \\
\hline & $=7$ & HKD 30,000-34,999 \\
\hline & $=8$ & HKD 35,000-39,999 \\
\hline & $=9$ & HKD 40,000 or more \\
\hline
\end{tabular}

- ITS stands for the individual's intention to stay in his or her residential district;

- $B A G E$ stands for the age of the building in which the individual resides;

- $S A T$ stands for the individual's satisfaction with his or her building's conditions;

- IFM stands for the number of immediate family members living in the district, but not with the individual;

- FSI stands for the individual's frequency or regularity of social interaction with his or her neighbours;

- REL stands for the individual's perceived relationship with his or her neighbours; and

- DIST is a vector of dummies representing the districts.

The function $f(x)$ attempts to integrate socio-demographic factors (gender, age, household income, education level and employment status), residential experience (length of residence, housing tenure and intention to stay), housing characteristics (building age and location) and social network (regularity of contact, number of family members living nearby and the quality of one's relationship with neighbours). Table 1 describes the variables incorporated in Equation 1. 


\begin{tabular}{|c|c|c|}
\hline Variable & \multicolumn{2}{|c|}{ Description } \\
\hline \multicolumn{3}{|c|}{ Educational Attainment (EDU) } \\
\hline & $=1$ & Primary or below \\
\hline & $=2$ & Lower secondary \\
\hline & $=3$ & Upper secondary \\
\hline & $=4$ & Non-degree post-secondary \\
\hline & $=5$ & Bachelor's degree or higher \\
\hline \multicolumn{3}{|c|}{ Employment Status (EMP) } \\
\hline EMP_1 & $=1$ & If the respondent was an employer or self-employed, and zero if otherwise \\
\hline$E M P \_2$ & $=1$ & If the respondent was an employee, and zero if otherwise \\
\hline EMP_3 & $=1$ & If the respondent was a student or housewife, and zero if otherwise \\
\hline$E M P_{-} 4$ & $=1$ & If the respondent was retired, and zero if otherwise \\
\hline EMP_5 & $=1$ & If the respondent was unemployed, and zero if otherwise \\
\hline \multicolumn{3}{|c|}{ Tenure Type (TEN) } \\
\hline & $=1$ & If respondent was an owner-occupier, and zero if otherwise \\
\hline \multicolumn{3}{|c|}{ Length of Residence (LOR) } \\
\hline & \multicolumn{2}{|r|}{ Individual's length of residence at the current address, measured in the number of years } \\
\hline \multicolumn{3}{|c|}{ Intention to Stay in the District (ITS) } \\
\hline ITS_1 & $=1$ & If the respondent intended to stay in the district, and zero if otherwise \\
\hline ITS_2 & $=1$ & If the respondent did not intend to stay in the district, and zero if otherwise \\
\hline ITS_3 & $=1$ & $\begin{array}{l}\text { If the respondent had not decided if he or she would continue to stay in the } \\
\text { district, and zero if otherwise }\end{array}$ \\
\hline \multicolumn{3}{|c|}{ Building Age (BAGE) } \\
\hline & $=1$ & $30-39$ years \\
\hline & $=2$ & $40-49$ years \\
\hline & $=3$ & 50 years or more \\
\hline \multicolumn{3}{|c|}{ Satisfaction with Overall Building Conditions (SAT) } \\
\hline & $=1$ & Very dissatisfied \\
\hline & $=2$ & Dissatisfied \\
\hline & $=3$ & Neutral \\
\hline & $=4$ & Satisfied \\
\hline & $=5$ & Very satisfied \\
\hline \multicolumn{3}{|c|}{ Immediate Family Members (IFM) } \\
\hline & \multicolumn{2}{|c|}{ Number of the respondent's immediate family members living in the district } \\
\hline \multicolumn{3}{|c|}{ Frequency of Social Interaction with Neighbours (FSI) } \\
\hline & $=1$ & Rare or never \\
\hline & $=2$ & Seldom \\
\hline & $=3$ & Often \\
\hline & $=4$ & Very Often \\
\hline \multicolumn{3}{|c|}{ Perceived Relationship with Neighbours (REL) } \\
\hline & $=1$ & Very poor \\
\hline & $=2$ & Poor \\
\hline & $=3$ & Average \\
\hline & $=4$ & Good \\
\hline & $=5$ & Very good \\
\hline \multicolumn{3}{|c|}{ District $(D I S T)$} \\
\hline CW & $=1$ & If the respondent lived in Central and Western, and zero if otherwise \\
\hline WC & $=1$ & If the respondent lived in Wanchai, and zero if otherwise \\
\hline YTM & $=1$ & If the respondent lived in Yau Tsim Mong, and zero if otherwise \\
\hline SSP & $=1$ & If the respondent lived in Sham Shui Po, and zero if otherwise \\
\hline
\end{tabular}


Table 2: Residential distribution of the households surveyed in the four districts.

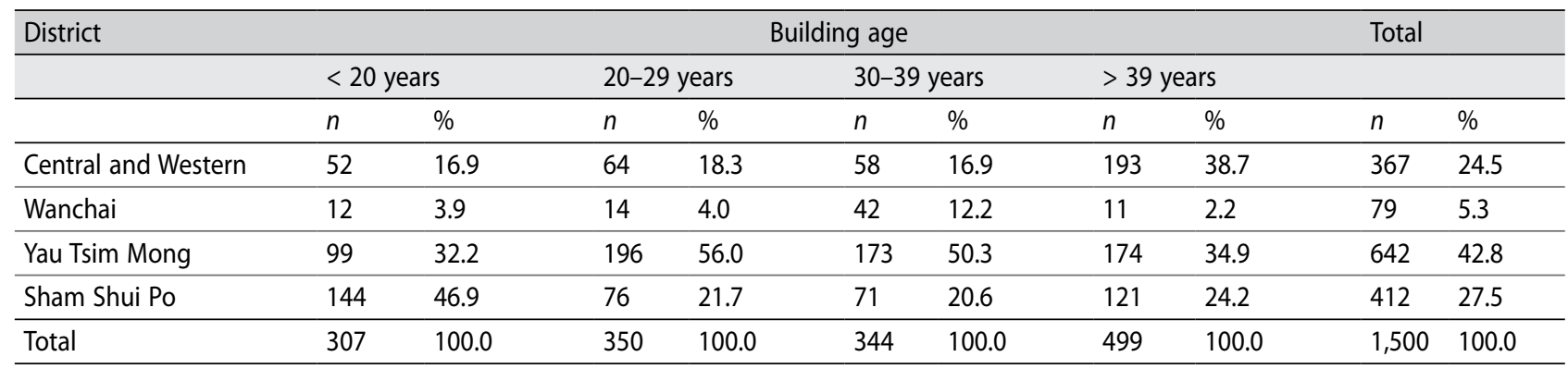

Table 3: Distribution of the explanatory variables by attitudinal choices.

\begin{tabular}{|c|c|c|c|c|c|c|c|c|}
\hline \multirow[t]{2}{*}{ Variables } & \multicolumn{2}{|c|}{ Pro-rehabilitation } & \multicolumn{2}{|c|}{ Pro-redevelopment } & \multicolumn{2}{|c|}{ Neutral } & \multicolumn{2}{|l|}{ Total } \\
\hline & $n$ & $\%$ & $n$ & $\%$ & $n$ & $\%$ & $n$ & $\%$ \\
\hline \multicolumn{9}{|l|}{ Gender (GEN) } \\
\hline$(=1)$ Male & 73 & 45.6 & 127 & 43.9 & 203 & 51.5 & 403 & 47.8 \\
\hline$(=0)$ Female & 87 & 54.4 & 162 & 56.1 & 191 & 48.5 & 440 & 52.2 \\
\hline Total & 160 & 100.0 & 289 & 100.0 & 394 & 100.0 & 843 & 100.0 \\
\hline \multicolumn{9}{|l|}{ Age (AGE) } \\
\hline$(=1) 19$ years old or less & 8 & 5.0 & 5 & 1.7 & 12 & 3.0 & 25 & 3.0 \\
\hline$(=2)$ 20-29 years old & 15 & 9.4 & 17 & 5.9 & 42 & 10.7 & 74 & 8.8 \\
\hline$(=3)$ 30-39 years old & 35 & 21.3 & 34 & 11.8 & 50 & 12.7 & 118 & 14.0 \\
\hline$(=4)$ 40-49 years old & 29 & 18.1 & 69 & 23.9 & 62 & 15.7 & 160 & 19.0 \\
\hline$(=5)$ 50-59 years old & 36 & 22.5 & 68 & 23.5 & 69 & 17.5 & 173 & 20.5 \\
\hline$(=6)$ 60-69 years old & 13 & 8.1 & 46 & 15.9 & 59 & 15.0 & 118 & 14.0 \\
\hline$(=7) 70$ years old or more & 25 & 15.6 & 49 & 17.0 & 100 & 25.4 & 174 & 20.6 \\
\hline Refused to answer & 0 & 0.0 & 1 & 0.3 & 0 & 0.0 & 1 & 0.1 \\
\hline Total & 160 & 100.0 & 289 & 100.0 & 394 & 100.0 & 843 & 100.0 \\
\hline \multicolumn{9}{|l|}{ Monthly household income (INC) } \\
\hline$(=1)$ below HKD 6,000 & 29 & 18.1 & 47 & 16.3 & 87 & 22.1 & 163 & 19.3 \\
\hline (= 2) HKD 6,000-9,999 & 20 & 12.5 & 40 & 13.8 & 64 & 16.2 & 124 & 14.7 \\
\hline (= 3) HKD 10,000-14,999 & 32 & 20.0 & 52 & 18.0 & 75 & 19.0 & 159 & 18.9 \\
\hline$(=4)$ HKD 15,000-19,999 & 23 & 14.4 & 44 & 15.2 & 56 & 14.2 & 123 & 14.6 \\
\hline (= 5) HKD 20,000-24,999 & 18 & 11.3 & 40 & 13.8 & 30 & 7.6 & 88 & 10.4 \\
\hline$(=6)$ HKD 25,000-29,999 & 13 & 8.1 & 16 & 5.5 & 10 & 2.5 & 39 & 4.6 \\
\hline (= 7) HKD 30,000-34,999 & 7 & 4.4 & 20 & 6.9 & 22 & 5.6 & 49 & 5.8 \\
\hline$(=8)$ HKD 35,000-39,999 & 10 & 6.3 & 16 & 5.5 & 13 & 3.3 & 39 & 4.6 \\
\hline (= 9) HKD 40,000 or more & 4 & 2.5 & 5 & 1.7 & 7 & 1.8 & 16 & 1.9 \\
\hline Refused to answer & 4 & 2.5 & 9 & 3.1 & 30 & 7.6 & 43 & 5.1 \\
\hline Total & 160 & 100.0 & 289 & 100.0 & 394 & 100.0 & 843 & 100.0 \\
\hline \multicolumn{9}{|l|}{ Educational attainment (EDU) } \\
\hline$(=1)$ Primary or less & 30 & 18.8 & 92 & 31.8 & 140 & 35.5 & 262 & 31.1 \\
\hline (= 2) Lower secondary & 37 & 23.1 & 60 & 20.8 & 103 & 26.1 & 200 & 23.7 \\
\hline (= 3) Upper secondary & 59 & 36.9 & 95 & 32.9 & 95 & 24.1 & 249 & 29.5 \\
\hline$(=4)$ Non-degree post-secondary & 8 & 5.0 & 14 & 4.8 & 21 & 5.3 & 43 & 5.1 \\
\hline (= 5) Bachelor's degree or higher & 26 & 16.3 & 27 & 9.3 & 29 & 7.4 & 82 & 9.7 \\
\hline Refused to answer & 0 & 0.0 & 1 & 0.4 & 6 & 1.5 & 7 & 0.8 \\
\hline Total & 160 & 100.0 & 289 & 100.0 & 394 & 100.0 & 843 & 100.0 \\
\hline \multicolumn{9}{|l|}{ Employment status (EMP) } \\
\hline$\left(E M P \_1=1\right)$ Employer or self-employed & 13 & 8.1 & 24 & 8.3 & 28 & 7.1 & 65 & 7.8 \\
\hline$($ EMP_2 = 1) Employee & 83 & 51.9 & 122 & 42.2 & 135 & 34.3 & 340 & 40.7 \\
\hline
\end{tabular}




\begin{tabular}{|c|c|c|c|c|c|c|c|c|}
\hline \multirow[t]{2}{*}{ Variables } & \multicolumn{2}{|c|}{ Pro-rehabilitation } & \multicolumn{2}{|c|}{ Pro-redevelopment } & \multicolumn{2}{|c|}{ Neutral } & \multicolumn{2}{|l|}{ Total } \\
\hline & $n$ & $\%$ & $n$ & $\%$ & $n$ & $\%$ & $n$ & $\%$ \\
\hline \multicolumn{9}{|l|}{ Employment status (EMP) } \\
\hline$\left(E M P \_3=1\right)$ Student or housewife & 25 & 15.6 & 72 & 24.9 & 109 & 27.7 & 206 & 24.7 \\
\hline$\left(E M P \_4=1\right)$ Retired & 34 & 21.3 & 59 & 20.4 & 112 & 28.4 & 205 & 24.6 \\
\hline (EMP_5 = 1) Unemployed* & 5 & 3.1 & 12 & 4.2 & 10 & 2.5 & 27 & 3.2 \\
\hline Total & 160 & 100.0 & 289 & 100.0 & 394 & 100.0 & 843 & 100.0 \\
\hline \multicolumn{9}{|l|}{ Tenure Type (TEN) } \\
\hline (= 1) Owner-occupier & 123 & 76.9 & 231 & 79.9 & 227 & 57.6 & 581 & 68.9 \\
\hline$(=0)$ Others* & 36 & 22.5 & 58 & 20.1 & 165 & 41.9 & 259 & 30.7 \\
\hline Refused to answer & 1 & 0.6 & 0 & 0.0 & 2 & 0.5 & 3 & 0.4 \\
\hline Total & 160 & 100.0 & 289 & 100.0 & 394 & 100.0 & 843 & 100.0 \\
\hline \multicolumn{9}{|l|}{ Intention to stay in the district (ITS) } \\
\hline$($ ITS_1 = 1) Yes & 123 & 76.9 & 182 & 63 & 195 & 49.5 & 500 & 59.3 \\
\hline$($ ITS_2 = 1) No & 12 & 7.5 & 28 & 9.7 & 40 & 10.1 & 80 & 9.5 \\
\hline$($ ITS_3 = 1) Not yet decided* & 25 & 15.6 & 79 & 27.3 & 159 & 40.4 & 263 & 31.2 \\
\hline Total & 160 & 100.0 & 289 & 100.0 & 394 & 100.0 & 843 & 100.0 \\
\hline \multicolumn{9}{|l|}{ Building age (BAGE) } \\
\hline$(=1) 30-39$ years & 76 & 47.5 & 113 & 39.1 & 155 & 39.3 & 344 & 40.8 \\
\hline$(=2)$ 40-49 years & 80 & 50.0 & 155 & 53.6 & 200 & 50.8 & 435 & 51.6 \\
\hline$(=3) 50$ years or more & 4 & 2.5 & 21 & 7.3 & 39 & 9.9 & 64 & 7.6 \\
\hline Total & 160 & 100.0 & 289 & 100.0 & 394 & 100.0 & 843 & 100.0 \\
\hline \multicolumn{9}{|c|}{ Satisfaction with the overall conditions of the building (SAT) } \\
\hline$(=1)$ Very dissatisfied & 1 & 0.6 & 5 & 1.7 & 4 & 1.0 & 10 & 1.2 \\
\hline (= 2) Dissatisfied & 1 & 0.6 & 26 & 9.0 & 29 & 7.3 & 56 & 6.6 \\
\hline$(=3)$ Neutral & 38 & 23.8 & 99 & 34.3 & 171 & 43.4 & 308 & 36.5 \\
\hline (= 4) Satisfied & 116 & 72.5 & 153 & 52.9 & 180 & 45.7 & 449 & 53.3 \\
\hline$(=5)$ Very satisfied & 4 & 2.5 & 6 & 2.1 & 10 & 2.5 & 20 & 2.4 \\
\hline Total & 160 & 100.0 & 394 & 100.0 & 289 & 100.0 & 843 & 100.0 \\
\hline \multicolumn{9}{|c|}{ Frequency of social interaction with neighbours (FSI) } \\
\hline (= 1) Rare & 37 & 23.1 & 38 & 13.1 & 113 & 28.7 & 188 & 22.3 \\
\hline (= 2) Seldom & 68 & 42.5 & 143 & 49.5 & 169 & 42.9 & 380 & 45.1 \\
\hline$(=3)$ Often & 46 & 28.8 & 100 & 34.6 & 102 & 25.9 & 248 & 29.4 \\
\hline$(=4)$ Very often & 6 & 3.7 & 6 & 2.1 & 7 & 1.8 & 19 & 2.3 \\
\hline Refused to answer & 3 & 1.9 & 3 & 0.7 & 2 & 0.7 & 8 & 0.9 \\
\hline Total & 160 & 100.0 & 394 & 100.0 & 289 & 100.0 & 843 & 100.0 \\
\hline \multicolumn{9}{|c|}{ Perceived relationship with neighbours (REL) } \\
\hline$(=1)$ Very poor & 1 & 0.6 & 1 & 0.3 & 2 & 0.5 & 4 & 0.5 \\
\hline$(=2)$ Poor & 2 & 1.2 & 1 & 0.3 & 12 & 3.0 & 15 & 1.8 \\
\hline (= 3) Average & 59 & 36.9 & 131 & 45.3 & 222 & 56.3 & 412 & 48.9 \\
\hline$(=4)$ Good & 55 & 34.4 & 115 & 39.8 & 115 & 29.2 & 285 & 33.8 \\
\hline$(=5)$ Very good & 19 & 11.9 & 22 & 7.6 & 14 & 3.5 & 55 & 6.5 \\
\hline Refused to answer & 24 & 15.0 & 29 & 6.5 & 19 & 6.6 & 72 & 8.5 \\
\hline Total & 160 & 100.0 & 394 & 100.0 & 289 & 100.0 & 843 & 100.0 \\
\hline \multicolumn{9}{|l|}{ District (DIST) } \\
\hline$(C W=1)$ Central \& Western & 62 & 38.8 & 81 & 28.0 & 108 & 27.4 & 251 & 29.7 \\
\hline$(W C=1)$ Wanchai & 13 & 8.1 & 27 & 9.3 & 13 & 3.3 & 53 & 6.3 \\
\hline$(Y T M=1)$ Yau Tsim Mong & 80 & 50.0 & 135 & 46.7 & 132 & 33.5 & 347 & 41.2 \\
\hline$(S S P=1)$ Sham Shui Po* & 5 & 3.1 & 46 & 16.0 & 141 & 35.8 & 192 & 22.8 \\
\hline Total & 160 & 100.0 & 289 & 100.0 & 394 & 100.0 & 843 & 100.0 \\
\hline
\end{tabular}

Note: $\left({ }^{*}\right)$ denotes reference dummies in the ordered probit analysis.

Urbani izziv, volume 23, no. 1, 2012 


\subsection{Data collection}

We collected the data for empirically testing Equation 1 through a structured survey conducted from May to October 2008. The 2006 Population by-census revealed that the total number of households in CW, WC, YTM and SSP were $88,088,55,234,100,589$ and 126,103, respectively (Census and Statistics Department, 2007). A total of 1,500 households were randomly interviewed, comprising 367 from CW, 79 from WC, 642 from YTM and 412 from SSP. Table 2 shows the distribution of the respondents with reference to locality and building age. Among the 1,500 residents interviewed, 843 resided in private residential buildings that were at least 30 years old. Only this group of respondents were asked about their attitudes toward the two mainstream renewal approaches for regenerating the buildings they lived in. Buildings that were less than 30 years old were disregarded because private residential buildings in Hong Kong built from the 1980s onwards are generally less prone to dilapidation (Adams \& Hastings, 2001).

\section{Survey findings, analysis results and discussion}

\subsection{Findings from the survey}

As shown in Table 1 , most of the explanatory variables in Equation 1 were either dichotomous or ordinal, except for $L O R$ and IFM, which are continuous. For those 843 respondents living in older buildings, the lengths of residence at their current addresses ranged from 0.08 to 60 years, with a mean of 16.4 years and a standard deviation of 13.3. On average, the respondents had 1.17 immediate family members living in the district, but not in the same flat as they lived in. As for the non-continuous variables, their distributive statistics are summarised in Table 3. Altogether, 29.7\% of the respondents resided in CW, 6\% in WC, 41\% in YTM and 23\% in SSP. In terms of gender, $47.8 \%$ of the respondents were male. Over half of the respondents (55.1\%) were age 50 or older. Given that the median monthly household income of all of Hong Kong was HKD 17,250 in 2006 (Census and Statistics Department, 2007), at least half of the households in the survey earned less than this figure. Regarding education level, only $14.8 \%$ of the respondents received a post-secondary education. The sample was dominated by employees (40.7\%), and the "retired" and "student and housewife" groups together comprised almost half the sample (49.3\%). There were 581 (68.9\%) owner-occupiers in the sample, and $40.8 \%$ and $51.6 \%$ of them lived in buildings 30 to 39 years and 40 to 49 years old, respectively. Another $7.6 \%$ resided in buildings that were at least 50 years old.

When asked whether they would continue residing in their current districts if their flats needed to be demolished, 59.3\% of the respondents said yes and $9.5 \%$ responded negatively. Despite the fact that $31.2 \%$ of the respondents had not yet decided, the findings indicated a strong attachment of the respondents to their districts. For example, over $40 \%$ of the respondents enjoyed the company of their neighbours, whereas only $2.3 \%$ thought poorly of them. However, $67.4 \%$ of the respondents disclosed that they seldom or rarely socialised with their neighbours. This confirmed the observation by Ray Forrest et al. (2002) that neighbourly contact in Hong Kong was weak. The proportion of respondents satisfied with the overall conditions of their buildings amounted to $55.7 \%$, with only $7.8 \%$ dissatisfied. As for attitudes towards redevelopment and rehabilitation, it was striking that 394 respondents out of $843(46.7 \%)$ did not indicate a particular preference for either option. Among the rest, 289 (34.3\%) preferred redevelopment and $160(19.0 \%)$ opted for rehabilitation. Further analysis is required to determine the characteristics of those respondents that opted for redevelopment or rehabilitation.

\subsection{Results of ordered probit analysis}

Because the dependent variable in Equation 1 is cardinal and ordered (from -3 to +3 ) in nature, a simple ordinary least-squares technique cannot generate credible estimation results (McKelvey \& Zavoina, 1975; Lu, 1999). In this regard, an ordered probit analysis was performed to estimate the equation. After truncating for missing data, we included 714 observations in the analysis, the results of which are presented in Table 4. The likelihood ratio (LR) statistic for the analysis was 63.96 (statistically significant at the $1 \%$ level), which implied that the subject model performed better than the null model in predicting the respondents' attitudes toward rehabilitation and redevelopment. As the analysis results indicated, the gender and education level of the respondents did not significantly affect their choices if all other variables were controlled. The estimated coefficients of the variables INC and $A G E$ were positive and statistically significant at the $5 \%$ level. These results implied that inclination towards redevelopment increased with the respondent's monthly household income and age. That is, wealthier and older respondents tended to support redevelopment, ceteris paribus.

Such findings are rather counterintuitive because many previous studies (e.g., Eckert, 1979; 1983; Chui, 2001, 2008) argued that redevelopments harmed older residents in various ways. Older respondents in this study preferred redevelopment to rehabilitation probably because of the inadequacies of their living built environments. For example, the absence of lifts in most old tenement blocks reduces the mobility of the elderly, affecting their physical and social wellbeing. Although rehabilitation can generally improve a building's condition, few things, if any, can be done to enhance the properties' acces- 
Table 4: Results of the ordered probit analysis.

\begin{tabular}{|c|c|c|c|c|}
\hline Variable & Coefficient & Standard error & z-statistic & \\
\hline GEN & 0.075035 & 0.095877 & 0.782616 & \\
\hline$A G E$ & 0.083936 & 0.034209 & 2.453628 & $* *$ \\
\hline INC & 0.053528 & 0.024274 & 2.205116 & $* *$ \\
\hline$E D U$ & -0.065055 & 0.043642 & -1.490650 & \\
\hline EMP_1 & -0.332779 & 0.274057 & -1.214269 & \\
\hline EMP_2 & -0.184300 & 0.238810 & -0.771741 & \\
\hline EMP_3 & -0.123556 & 0.240729 & -0.513260 & \\
\hline EMP_4 & -0.484834 & 0.253495 & -1.912596 & * \\
\hline TEN & 0.184545 & 0.102457 & 1.801190 & * \\
\hline$L O R$ & 0.000416 & 0.003901 & 0.106652 & \\
\hline ITS_1 & -0.104617 & 0.085180 & -1.228185 & \\
\hline ITS_2 & 0.119178 & 0.137294 & 0.868045 & \\
\hline BAGE & 0.179490 & 0.066982 & 2.679688 & $* * *$ \\
\hline SAT & -0.263234 & 0.062631 & -4.202954 & $* * *$ \\
\hline IFM & 0.000584 & 0.015750 & 0.037086 & \\
\hline FSI & 0.096921 & 0.061390 & 1.578767 & \\
\hline REL & -0.002759 & 0.075035 & -0.036766 & \\
\hline$C W$ & -0.058582 & 0.095253 & -0.615010 & \\
\hline$W C$ & 0.628215 & 0.228916 & 2.744304 & $* * *$ \\
\hline YTM & 0.173540 & 0.095460 & 1.817926 & $*$ \\
\hline Dependent variable & CHOICE & No. of observations & 714 & \\
\hline Pseudo $R$-squared & 0.032389 & Akaike info criterion & 2.749033 & \\
\hline Schwarz criterion & 2.915479 & Log likelihood & -955.4046 & \\
\hline Hannan-Quinn criterion & 2.813315 & LR statistic & 63.96037 & *** \\
\hline
\end{tabular}

Notes: $\left({ }^{* *}\right),\left({ }^{* *}\right)$ and $(*)$ denote statistical significance at the $1 \%, 5 \%$ and $10 \%$ levels, respectively.

sibility due to the physical and technical constraints of such buildings. Redevelopment, in contrast, can offer an opportunity to either incorporate better designs and provisions into new buildings or to move the residents affected to other buildings with better accessibility. In light of this, poor building performance may predispose older respondents to redevelopment. The adaptability of a building to cater to the special needs of its elderly residents would be a great concern for rehabilitation.

In fact, this explanation is in line with the other findings from the empirical analysis. As the analysis results indicated, it is more likely for respondents living in older buildings to tend to favour redevelopment. From the perspective of structural safety, buildings that are at least 40 years old are prone to many problems (Adams \& Hastings, 2001). For example, the use of seawater in mixing concrete, poor workmanship and inadequate supervision during the 1960s and 1970s rendered buildings constructed in that era vulnerable to steel reinforcement corrosion leading to concrete spalling. From the residents' viewpoint, their buildings, if not totally irreparable, are not fit to rehabilitate cost-effectively. Residents of older buildings were hence more likely to pick redevelopment as their choice. At the same time, the analysis results revealed that respondents dissatisfied with the overall conditions of their buildings also tended to support redevelopment.

The association between respondents' age and inclination to redevelop should be interpreted with care. The analysis results also showed that, compared to those that were unemployed, retired respondents tended to prefer rehabilitation, which is seemingly contradictory to the finding stated earlier. The divergence can be explained from the perspective of one's living style. Compared to older residents that were still working, the retired elderly usually have more time to spend in their own neighbourhoods. Therefore, they may have a strong bond to the local social fabric and would not prefer redevelopment, which would disturb or even destroy their social networks built up over many years.

Regarding housing tenure, owner-occupiers tended to support redevelopment compared to respondents in other tenure modes, ceteris paribus. On the other hand, it is rather surprising to see that one's length of residence in his or her current address $(L O R)$ and intention to stay (ITS) in the district turned out to be statistically insignificant factors (even at the 10\% level). Moreover, variables representing the quality of existing 
social networks in the district (FSI, IFM and REL) did not have any significant effect on a respondent's attitude, even at the $10 \%$ level.

As far as the locational factor is concerned, compared to those in CW and SSP, respondents from WC and YTM preferred redevelopment more. These findings diverged from those of the District Aspiration Studies (DASs), which was commissioned by the District Councils in late 2009 (Urban Renewal Authority, 2010). The DASs revealed a strong inclination to rehabilitation by residents in WC. The divergence between these findings might have originated from their different opinion collection processes. We used a structured survey of randomly sampled households for this study, and workshops, in addition to surveys, were held to collate people's views in the DAS for WC. The findings from the workshops may be subjected to selection bias because active participants in these workshops were more likely to be preservationists. In addition, respondents in the DAS for WC had mixed backgrounds, including local residents, people that worked in the district, visitors to the district and local retail business operators, whereas only residents in older private buildings were surveyed for this study. These methodological and respondent differences contributed to the divergent findings.

\subsection{Discussion}

The analysis results suggested that building quality, be it measured by residents' satisfaction or by building age, was one of the major determinants of their choices between the two urban renewal approaches. When asked about the key reasons for their choices, 49 of the 160 pro-rehabilitation respondents (30.6\%) opined that their buildings were not so dilapidated. For those choosing redevelopment, $43.6 \%$ thought that their buildings were too decrepit. Therefore, perceived building quality played a pivotal role in shaping the attitudes of the respondents. This finding signifies that the way people intervene in their built environment is contingent upon the person's perceptions of the quality of the building they live in.

The results of the analysis also indicate that our minds should not be preoccupied by "logical" thinking when determining the best option for an urban renewal project. For example, it is commonly perceived that local social networks should be preserved in renewal projects. In addition, much literature had identified the elderly as one of the most vulnerable groups in redevelopments. It seems logical that the elderly are against redevelopment, which has been accused of disrupting the social fabric and displacing the disadvantaged. However, the empirical findings of this study revealed that older respondents in the areas surveyed preferred redevelopment to rehabilitation. As implied by these findings, redevelopment is not necessarily socially unacceptable in an area with a high concentration of the elderly. Many other factors, such as the employment status and lifestyle of the local residents, must be considered when evaluating the potential impact of a renewal project. It is highly probable that the effects of a resident's socioeconomic status on his or her attitude also vary in a social and cultural context. More importantly, understanding stakeholders' aspirations or preferences under each scenario is essential to a socially desirable and sustainable project.

Furthermore, the research findings revealed that domestic tenants, rather than owner-occupiers, were opposed to redeveloping the buildings in which they lived. This tenure-based empirical finding can be a sign of the discontent of the domestic tenants with the current compensation policy for redevelopment. Indeed, the current compensation mechanisms for the residents affected by redevelopment are skewed. Only property owners are compensated in the case of redevelopment led by the private sector. Tenants or lessees are not entitled to any reparation other than damages for early lease termination from their landlords. In a redevelopment project initiated by the Urban Renewal Authority (URA) before the enactment of the Landlords and Tenants (Consolidation) (Amendment) Ordinance 2004, the authority offered ex-gratia cash payments to the domestic tenants affected. For new projects carried out by the URA, the domestic tenants affected can choose between re-housing in public housing and cash compensation based on 3.5 times the rateable value of the properties occupied. However, these payments are not as attractive as those offered to the property owners. The government and URA should consider reviewing the compensation policy for domestic tenants in redevelopment projects.

As shown by the findings from the survey, the residents in Hong Kong's older urban areas were divided over the preferred approach to renewing their buildings. Although the government took a bold and determined step to engage the public in the comprehensive review of the city's urban renewal strategy in 2008 and 2009, it seems that community involvement still remains at the level of overall strategy formulation and has not moved down to the level of project planning and operation. As Avi Friedman (2007) cautioned, urban renewal is likely to fail if the residents affected are not involved in the process. The renewal authorities and their agents should work with the local community on the strategy for each project (Percy, 2003). This can reveal the needs of the local community and reduce the chances of other social problems occurring, such as social exclusion (Stubbs, 2004).

The previous section highlighted that the findings of a community aspirations survey for urban renewal may be sensitive to the methodology adopted. For the sake of public accountabil- 
ity and credibility, the URA or related organisations should have a set of consistent and transparent guidelines for conducting community aspirations surveys for urban renewal projects in the future. Serving as a preliminary study, this study targeted only private housing residents. The views of other stakeholders, including local retail operators and workers in the districts, should also be included to produce a comprehensive evaluation of each community's aspirations.

\section{Conclusion}

Urban renewal is an urgent resort to address rapid urban decay due to building dilapidation. Each redevelopment or rehabilitation approach has its own strengths and limitations. Given the significance of community reactions to sustainable urban renewal, this study assessed how residents in older districts perceived the two mainstream approaches of urban renewal through a structured survey. The survey findings revealed that, among those residents that were not indifferent to either option, redevelopment was a more preferred option. Based on the ordered probit analysis of the survey data, the authors found that building age, the respondent's age, household income, retirement status, housing tenure and satisfaction with the conditions of one's building were significant determinants of an individual's attitude towards either urban renewal approach. On the other hand, both attitudes straddled gender, education level, length of residence, intention to stay and other social network characteristics.

This study revealed some divergent views towards the two main options for urban renewal. Therefore a balanced strategy of urban renewal is needed for the long-term sustainable management of a city's building stock. Given the uniqueness of each urban renewal project (Fung \& Yau, 2009), a strategy for implementing each project should be specifically planned. Without input from stakeholders, a top-down approach cannot achieve a balanced and sustainable urban renewal strategy in the current "stakeholder society". Social conditions and community aspirations should be first assessed at the beginning of each project's planning process. More importantly, the community should be genuinely engaged in key decision-making exercises to reduce instances of injustice and social exclusion. Undoubtedly, different parties will have different priorities in a renewal project. Consensus building among the stakeholders is thus essential, but will be challenging in most cases. Although some studies (e.g., Sheffield, 1999; Dennis, 2006) have proposed the use of advanced techniques and technologies in urban planning, there should have been more studies on consensus building or collaborative decision-making for urban renewal. The applicability of methods like the urban decision room proposed by Neil Mayer et al. (2005) for urban renewal warrants vigilant consideration.

\section{Daniel Chi Wing Ho}

The University of Hong Kong, Department of Real Estate and Construction, Pokfulam Road, Hong Kong

E-mail: danielho@hku.hk

\section{Yung Yau}

City University of Hong Kong, Department of Public and Social

Administration, Kowloon Tong, Hong Kong

\section{Chi Kwong Law}

The University of Hong Kong, Department of Social Work and Social Administration, Pokfulam Road, Hong Kong

Sun Wah Poon

The University of Hong Kong, Department of Real Estate and Construction, Pokfulam Road, Hong Kong

\section{Hak Kwong Yip}

Policy 21 Limited, Hong Kong

\section{Ervi Liusman}

The University of Hong Kong, Department of Real Estate and Construction, Pokfulam Road, Hong Kong

\section{Notes}

[1] The amount of ex-gratia cash payment varies with household size. Under no circumstance is it less than HKD 70,000 for a one-person household and HKD 80,000 for a two-person or larger household.

${ }^{[2]}$ Tenants opting for re-housing must fulfil the eligibility criteria stated in the application for public housing of the Hong Kong Housing Authority or Hong Kong Housing Society.

[3] Tenants may also be offered a cash incentive equal to 0.5 times the rateable value on top of the ex-gratia payment, subject to certain eligibility conditions.

\section{Acknowledgements}

The authors gratefully acknowledge the financial support provided by the Research Grants Council of the Hong Kong Special Administrative Region (Project No. 7009-PPR-4), which made this study possible.

\section{References}

Adams, D. \& Hasting, E. M. (2001) Urban renewal in Hong Kong: Transition from development corporation to renewal authority. Land Use Policy, 18(3), pp. 245-258. DOI: 10.1016/S0264-8377(01)00019-9

Alker, S. \& McDonald, A. (2003) Incorporating sustainable development into redevelopment. Sustainable Development, 11(3), pp. 171-182. DOI: $10.1002 / s d .215$

Arthurson, K. (1998) Redevelopment of public housing estates: The Australian experience. Urban Policy and Research, 16(1), pp. 35-46. DOI: 10.1080/08111149808727746 
Balchin, P. N., Kieve, J. L. \& Bull, G. H. (1992) Urban land economics and public policy. London, Macmillan.

Brookes, J. A. \& Hughes, K. (1975) Housing redevelopment and rehabilitation. Town Planning Review, 46(2), pp. 215-225.

Census and Statistics Department (2007) 2006 Population by-census: Basic tables for district council districts. Hong Kong.

Chan, E. H. W. \& Lee, G. K. L. (2008a) Applicability in Hong Kong of London's experiences on urban redevelopment practices. Property Management, 26(2), pp. 125-137. DOI: 10.1108/02637470810866697

Chan, E. H. W. \& Lee, G. K. L. (2008b) Contribution of urban design to economic sustainability of urban renewal projects in Hong Kong. Sustainable Development, 16(6), pp. 353-364. DOI: 10.1002/sd.350

Chui, E. (2001) Doomed elderly in a booming city: Urban redevelopment and housing problems of elderly in Hong Kong. Housing, Theory and Society, 18(3-4), pp. 158-166. DOI: 10.1080/14036090152770528

Chui, E. (2008) Ageing in place in Hong Kong - challenges and opportunities in a capitalist Chinese city. Ageing International, 32(3), pp. 167182. DOI: $10.1007 / \mathrm{s} 12126-008-9015-2$

Cooper, I. (2001) Post occupancy evaluation - where are you? Building Research \& Information, 29(2), pp. 158-163. DOI: 10.1080/09613210010016820

Couch, C. \& Dennemann, A. (2000) Urban regeneration and sustainable development in Britain. Cities, 17(2), pp. 137-147. DOI: 10.1016/S02642751(00)00008-1

Danchev A. (2005) Social capital influence on sustainability of development (case study of Bulgaria). Sustainable Development, 13(1), pp. 2537. DOI: $10.1002 / \mathrm{sd} .243$

Dempsey, N., Bramley, G., Power, S. \& Brown, C. (in press) The social dimension of sustainable development: Defining urban social sustainability. Sustainable Development, DOI: 10.1002/sd.417.

Dennis, S. F. Jr. (2006) Prospects for qualitative GIS at the intersection of youth development and participatory urban planning. Environment and Planning A, 38(11), pp. 2039-2054. DOI: 10.1068/a3861

Eckert, J. K. (1979) Urban renewal and redevelopment: High risk for the marginally subsistent elderly. The Gerontologist, 19(5 Part 1), pp. 496502. DOI: 10.1093/geront/19.5_Part_1.496

Eckert, J. K. (1983) Dislocation and relocation of the urban elderly: Social networks as mediators of relocation stress. Human Organization, 42(1), pp. 39-45.

Edgar, B. \& Taylor, J. (2000) Housing. In: Roberts, P. \& Sykes, H. (eds.) Urban regeneration: A handbook. London, Sage.

Edwards, J. (1997) Urban policy: The victory of form over substance? Urban Studies, 34(56), pp. 825-843.

Fordham, G. (1995) Made to last. York, Joseph Rowntree Foundation.

Forrest, R., La Grange A. \& Yip N. M. (2002) Neighbourhood in a high rise, high density city: Some observations on contemporary Hong Kong. The Sociological Review, 50(2), pp. 215-240. DOI: 10.1111/1467954X.00364

Fried, M. (1966) Grieving for a lost home: Psychological costs of relocation. In: Wilson, J. Q. (ed.) Urban Renewal: The record and the controversy. Cambridge, MIT Press.

Friedman, A. (2007) Sustainable residential development: Planning and design for green neighborhoods. New York, McGraw-Hill.

Fung, W. B. \& Yau Y. (2009) Weightings of decision-making criteria for neighbourhood renewal: Perspectives of university students in Hong Kong. Journal of Urban Regeneration and Renewal, 2(3), pp. 238-258.
Hartman, C. (1964) The housing of relocated families. Journal of the American Institute of Planners, 30(4), pp. 266-286. DOI: 10.1080/01944366408978135

He, S. \& Wu, F. (2007) Socio-spatial impacts of property-led redevelopment on China's urban neighbourhoods. Cities, 24(3), pp. 194-208. DOI: 10.1016/j.cities.2006.12.001

Ho, D. C. W., Chau, K. W., Cheung, A. K. C., Yau, Y., Wong, S. K., Leung, H. F., et al. (2008) A survey of the health and safety conditions of apartment buildings in Hong Kong. Building and Environment, 43(5), pp. 764-775. DOI: 10.1016/j.buildenv.2007.01.035

Ho, D. C. W., Leung, H. F., Wong, S. K., Cheung, A. K. C, Lau, S. S. Y., Wong, W. S., et al. (2004) Assessing the health and hygiene performance of apartment buildings. Facilities, 22(3/4), pp. 58-69. DOI: 10.1108/02632770410527789

Ho, D. C. W. \& Yau, Y. (2004) Building safety and condition index: Benchmarking tool for maintenance managers. Paper presented at the $\mathrm{CIB}$ W70 Facilities Management and Maintenance Symposium 2004, 7-8 December, Hong Kong. Typescript.

Home Affairs Department (2010) Database of private buildings in Hong Kong. Available at: https://bmis.buildingmgt.gov.hk/eng/index.php (accessed 3 May 2010).

Hopwood, B., Mellor, M. \& O'Brien, G. (2005) Sustainable development: Mapping different approaches. Sustainable Development, 13(1), pp. 3852. DOI: $10.1002 / \mathrm{sd} .244$

Hui, E. C. M, Wong, J. T. Y. \& Wan, J. K. M. (2008) The evidence of value enhancement resulting from rehabilitation. Facilities, 26(1-2), pp. 16-32. DOI: $10.1108 / 02632770810840282$

Jackson, L. E. (2003) The relationship of urban design to human health and condition. Landscape and Urban Planning, 64(4), pp. 191-200. DOI: 10.1016/S0169-2046(02)00230-X

Jacobs, B. \& Dutton, C. (2000). Social and community issues. In: Roberts, P. \& Sykes, H. (eds.) Urban regeneration: A handbook. London, Sage.

Jacobs, J. (1961) The death and life of great American cities. New York Random House.

Juan, Y. K., Gao, P. \& Wang, J. (2010) A hybrid decision support system for sustainable office building renovation and energy performance improvement. Energy and Buildings, 42(3), pp. 290-297. DOI: 10.1016/j. enbuild.2009.09.006

Keating, L. (2000) Redeveloping public housing: Relearning urban renewal's immutable lessons. APA Journal, 66(4), pp. 384-397.

Lloyd, M. G. (2002) Urban regeneration and community development in Scotland: Converging agendas for action. Sustainable Development, 10(3), pp. 147-154. DOI: 10.1002/sd.193

Loftman, P. \& Nevin, B. (1995) Prestige projects and urban regeneration in the 1980s and 1990s: A review of benefits and limitations. Planning Practice and Research, 10(3-4), pp. 209-315. DOI: $10.1080 / 02697459509696280$

Lu, M. (1999) Determinants of residential satisfaction: Ordered logit vs. regression models. Growth and Change, 30(2), pp. 264-287. DOI: 10.1111/0017-4815.00113

Mayer, I., Van Bueren, E., Bots, P., Van der Voort, H. \& Seijdel, R. (2005) Collaborative decisionmaking for sustainable urban renewal projects: A simulation-gaming approach. Environment and Planning B, 32(3), pp. 403-423. DOI: 10.1068/b31149

Mayer, N. (1981) Rehabilitation decisions in rental housing: An empirical analysis. Journal of Urban Economics, 10(1), pp. 76-84. DOI: 10.1016/0094-1190(81)90024-3 
McKelvey, R. D. \& Zavoina, W. (1975) A statistical model for the analysis of ordinal level dependent variables. Journal of Mathematical Sociology, 4(1), pp. 103-120. DOI: 10.1080/0022250X.1975.9989847

McLaren, D. (1989) "Action for cities" and the urban environment. Local Economy, 4(2), pp. 99-111. DOI: 10.1080/02690948908725981

Meegan, R. \& Mitchell, A. (2001) It's not community round here, it's neighbourhood: Neighbourhood change and cohesion in urban regeneration policies. Urban Studies, 38(12), pp. 2167-2194. DOI: 10.1080/00420980120087117

Mendelsohn, R. (1977) Empirical evidence on home improvement. Journal of Urban Economics, 4(4), pp. 459-468. DOI: 10.1016/00941190(77)90006-7

Messner, S. D. (1968) Urban redevelopment in Indianapolis: A benefit-cost analysis. Journal of Regional Science, 8(2), pp. 149-158. DOI: 10.1111/j.1467-9787.1968.tb01320.x

Mourao, J. \& Pedro, J. B. (2007) Sustainable housing: From consensual guidelines to broader challenges. In: Braganca, L., Pinheiro, M., Jalali, S., Mateus, R., Amoeda, R. \& Guedes, M. C. (eds.) Portugal SB07: Sustainable construction, material and practices. Amsterdam, IOS Press.

Needleman, L. (1965) The economics of housing. London, Staples Press.

Needleman, L. (1969) The comparative economics of improvement and new building. Urban Studies, 6(2), pp. 196-209. DOI: 10.1080/00420986920080261

Ng, M. K. (2002) Property-led urban renewal in Hong Kong: Any place for the community? Sustainable Development, 10(3), pp. 140-146. DOI: $10.1002 / \mathrm{sd} .189$

Ng, S. H., Kam, P. K. \& Pong, R. W. M. (2005) People living in ageing buildings: Their quality of life and sense of belonging. Journal of Environmental Psychology, 25(3), pp. 347-360. DOI: 10.1016/j. jenvp.2005.08.005

Oakley, S. (2007) Public consultation and place-marketing in the revitalisation of the Port Adelaide Waterfront. Urban Policy and Research, 25(1), pp. 113-128. DOI: 10.1080/08111140701225594

Ogdul, H. G. (2000) Social cohesion; Is it sufficient? Migrant communities in two disadvantaged neighborhoods in Istanbul. Geojournal, 51(4), pp. 321-328. DOI: 10.1023/A:1012222219170

O'Loughlin, J. \& Munski, D. C. (1979) Housing rehabilitation in the inner city: A comparison of two neighborhoods in New Orleans. Economic Geography, 55(1), pp. 52-70. DOI: 10.2307/142732

Percy, S. (2003) New agendas. In: Couch, C., Fraser, C. \& Percy, S. (eds.) Urban regeneration in Europe. Oxford, Blackwell Science. DOI: $10.1002 / 9780470690604 . c h 13$

Planning and Lands Bureau (2001) Urban renewal strategy. Hong Kong.

Price Waterhouse (1993) Evaluation of urban development grant, urban regeneration grant and city grant. London, HMSO.

Ribeiro, F. L. (2008) Urban regeneration economics: The case of Lisbon's old downtown. International Journal of Strategic Property Management, 12(3), pp. 203-213. DOI: 10.3846/1648-715X.2008.12.203-213

Roberts, P. (2000) Evolution, definition and purpose of urban regeneration. In: Roberts, P. \& Sykes, H. (eds.) Urban regeneration: A handbook. London, Sage.

Shear, W. B. (1983) Urban housing rehabilitation and move decision. Southern Economic Journal, 49(4), pp. 1030-1052. DOI: 10.2307/1058105

Sheffield, J. (1999) Electronically assisted dialogues for urban planning. Paper presented at the 32nd Annual Hawaii International Conference on System Sciences, 5-8 January, Maui, Hawaii. Typescript.

Shye, S. (1989) The systemic life quality model: A basis for urban renewal evaluation. Social Indicators Research, 21(4), pp. 343-378. DOI: 10.1007/BF00303952

Simons, R. A., Magner, A. J. \& Baku. E. (2003) Do housing rehabs pay their way? A national case study. The Journal of Real Estate Research, 25(4), pp. 431-461.

Stevens, C. A. (1995) Public housing redevelopment as social policy. Urban Policy and Research, 13(2), pp. 81-88. DOI: 10.1080/08111149508551659

Stubbs, M. (2004) Heritage-sustainability: Developing a methodology for the sustainable appraisal of the historic environment. Planning, Practice \& Research, 19(3), pp. 285-305. DOI: 10.1080/02697450420003 23229

Tam, V. W. Y. \& Tam, C. M. (2007) Crushed aggregate production from centralized combined and individual waste sources in Hong Kong. Construction and Building Materials, 21(4), pp. 879-886. DOI: 10.1016/j. conbuildmat.2005.12.016

Taylor, M. (2000) Communities in the lead: Power, organisational capacity and social capital. Urban Studies, 37(5-6), pp. 1019-1035. DOI: $10.1080 / 00420980050011217$

Travis, R. W. (1973) Place utility and social change in inner city historic space. Doctoral thesis. Chicago, University of Illinois.

Urban Renewal Authority (2010) Steering committee on review of the urban renewal strategy summary of findings of district aspiration studies SC Paper No. 14/2010. Hong Kong.

Warren, J. M. (1965) Conservation and rehabilitation of housing: An idea approaches adolescence. Michigan Law Review, 63(5), pp. 892-912. DOI: $10.2307 / 1286509$

Willmott, P. \& Young, M. (1957) Family and kinship in east London. London, Routledge.

Winston, N. (2010) Regeneration for sustainable communities? Barriers to implementing sustainable housing in urban areas. Sustainable Development, 18(6), pp. 319-330. DOI. 10.1002/sd.399

Wong, S. K., Cheung, A. K. C., Yau, Y., Ho, D. C. W. \& Chau, K. W. (2006) Are our residential buildings healthy and safe? A survey in Hong Kong. Structural Survey, 24(1), pp. 77-86. DOI: 10.1108/02630800610654432

Wood, C. (1991) Urban renewal: The British experience. In: Alterman, R. \& Cars, R. (eds.) Neighbourhood regeneration: An international evaluation. London, Mansell.

Yau, Y. (2008) Building conditions in Yau Tsim Mong, Hong Kong: Appraisal, exploration and estimation. Journal of Building Appraisal, 3(4), pp. 319-329. DOI: 10.1057/jba.2008.8

Yau, Y. (2009) Raziskava o sprejemljivosti komasacije za urbano prenovo $v$ Hongkongu [A study on the acceptability of land readjustment for urban regeneration in Hong Kong]. Urbani izziv 20(2), pp. 36-44 [105114]. DOI: 10.5379/urbani-izziv-en-2009-20-02-004

Yau, Y. (2010) Občutek pripadnosti skupnosti in sodelovanje lastnikov pri upravljanju večstanovanjskih stavb: raziskava v Hongkongu [Sense of community and homeowner participation in housing management: A study of Hong Kong]. Urbani izziv 21(1), pp. 51-60 [126-136]. DOI: 10.5379/urbani-izziv-en-2010-21-01-005

Yau, Y. (2011) Ali celovita sanacija vpliva na spremembo cen stanovanj? Študija primera v predelu Mongkok v Hongkong [Does comprehensive redevelopment change the housing price gradient? A case study in Mongkok, Hong Kong]. Urbani izziv 22(2), pp. 25-33 [98-106]. DOI: 10.5379/urbani-izziv-en-2011-22-02-003

Yau, Y. \& Cheng, C. Y. (2010) Applicability of land readjustment in urban regeneration in Hong Kong. Journal of Urban Regeneration and Renewal, 4(1), pp. 19-32. 
Yau, Y., Chau, K. W., Ho, D. C. W. \& Wong, S. K. (2008) An empirical study on the positive externality of building refurbishment. International Journal of Housing Markets and Analysis, 1(1), pp. 19-32. DOI: $10.1108 / 17538270810861139$

Yau, Y. \& Ho, L. C. (2008) To rehabilitate or redevelop? A study of the decision criteria for urban regeneration projects. Journal of Place Management and Development, 1(3), pp. 272-291. DOI: $10.1108 / 17538330810911262$

Yau, Y., Ho, D. C. W. \& Chau, K. W. (2008) Determinants of the safety performance of private multi-storey residential buildings in Hong Kong. Social Indicators Research, 89(3), pp. 501-521. DOI: 10.1007/s11205-0089246-3

Yau, Y., Ho, D. C. W., Chau, K. W. \& Lau, W. Y. (2009) Estimation algorithm for predicting the performance of private apartment buildings in Hong Kong. Structural Survey, 27(5), pp. 372-389. DOI: $10.1108 / 02630800911002639$

Yiftachel, O. \& Hedgcock, D. (1993) Urban social sustainability: The planning of an Australian city. Cities, 10(2), pp. 139-157. DOI: 10.1016/02642751(93)90045-K

Yiu, C. Y. (2007) Building depreciation and sustainable development. Journal of Building Appraisal, 3(2), pp. 97-103. DOI: 10.1057/palgrave. jba.2950072

Yiu, C. Y. \& Leung, A. Y. T. (2005) A cost-and-benefit evaluation of housing rehabilitation. Structural Survey, 23(2), pp. 138-151. DOI: 10.1108/02630800510593701 